\title{
Ceramic densification effect on corrosion resistance and thermal conductivity
}

\section{Efecto de la densificación en cerámicos en la resistencia a la corrosión y conductividad térmica}

\author{
ACOSTA-PEREZ, Emmanuel'†, SALAZAR-HERNÁNDEZ, Mercedes"”, MENDOZA-MIRANDA, \\ Juan Manuel' and SALAZAR-HERNÁNDEZ, Carmen'**
}

\begin{abstract}
Instituto Politécnico Nacional. Interdisciplinary Professional Unit of Engineering Campus Guanajuato. Av. Mineral de Valenciana No. 200 Col. Fracc. Industrial Puerto Interior, C.P. 36275 Silao de la Victoria, Guanajuato, Mexico.

"Department of Mining Engineering, Metallurgy and Geology. Universidad de Guanajuato. Ex Hacienda de San Matías S/N Colonia San Javier, C.P.36020, Guanajuato, Gto. Mexico.
\end{abstract}

\author{
ID $1^{\text {st }}$ Author: Emmanuel Acosta-Pérez / ORC ID: 0000-0002-3480-0028 \\ ID $1^{\text {st }}$ Coauthor: Mercedes, Salazar-Hernández / ORC ID: 0000-0001-8039-8124 \\ ID $2^{\text {nd }}$ Coauthor: Juan Manuel, Mendoza-Miranda / ORC ID: 0000-0003-4777-767X \\ ID $3^{\text {rd }}$ Coauthor: Carmen, Salazar-Hernández / ORC ID: 0000-0002-6901-2937
}

DOI: $10.35429 / J R D .2020 .18 .6 .11 .17$

Received: July 15, 2020; Accepted: December 20, 2020

\begin{abstract}
Thermal barrier Coatings (TBC) are a system of layers covering a surface with the aim to increase its insulation as well as protect the core of oxidation. In this paper the use of silica ceramics modified by polydimethylsiloxane (PDMS) as a new TBC for steel surface is proposed. The ceramics were obtained according to sol-gel methodology forming a stable sol mixing tetraethoxyetilsilicate (TEOS) at different percentage of PDMS (10, 20, 40 and 100\%); the gelling was done using DBTL (dibutildilaurate tin) as a polycondensation catalyst. Therefore, the sol was applied on AISI-1018 steel surface by inmersion and a densification process is applied. The ceramic was characterized by infrared spectroscopy to observe its silica structure changes produced by the thermal treatment. Finally, the analysis the densification effect on properties on thermal conductivity and corrosion resistance was carried on.
\end{abstract}

$\mathrm{SiO}_{2}$, PDMS, Densification, Thermal conductivity, Corrosion resistance

\begin{abstract}
Resumen
Las barreras térmicas (TBC) son un sistema de capas que cubren una superficie con el propósito de aislarla térmicamente y proteger el material contra la oxidación. En este proyecto se propone el uso de cerámicas de sílice modificadas con polidimetilsiloxano (PDMS) como un nuevo TBC para superficie de acero. Las cerámicas se obtuvieron de acuerdo con la metodología sol-gel, formando un sol estable mezclando tetraetoxietilsilicato (TEOS) con diferentes porcentajes en peso de PDMS (10, 20, 40 y 100\%). La gelificación se realizó empleando DBTL como catalizador de policondensación y las soluciones sol fueron aplicadas a superficies de acero AISI-1018 por inmersión; a estos recubrimientos se les realizó un tratamiento de densificación. Las cerámicas se caracterizaron por espectroscopía infrarroja para observar cambios en la estructura de la sílice modificada. Además, se analizó el efecto de densificación en propiedades tales como: la conductividad térmica y resistencia a la corrosión.
\end{abstract}

$\mathrm{SiO}_{2}$, PDMS, densificación, conductividad térmica, resistencia a la corrosión

Citation: ACOSTA-PEREZ, Emmanuel, SALAZAR-HERNÁNDEZ, Mercedes, MENDOZA-MIRANDA, Juan Manuel and SALAZAR-HERNÁNDEZ, Carmen. Ceramic densification effect on corrosion resistance and thermal conductivity. Journal of Research and Development. 2020. 6-18:11-17.

\footnotetext{
* Correspondence to the Author (Email: msalazarh@ipn.mx)

$\dagger$ Researcher contributing as first author.
} 


\section{Introduction}

Thermal Barrier coatings (TBC) are a system of layers that cover a surface with the the aim to increase its insulation as well as protect the core of oxidation in chemically agresive environments and operating at high temperatures. Thus, in a core without TBC and unidimensional heat transfer occurs, the temperature in both side are practically the same, Figure 1a shows the case of a heat source at $150^{\circ} \mathrm{C}$ where heat flows through a material core, the opposite temperature reaches $130^{\circ} \mathrm{C}$ without TBC. Appling a TBC on the surface of the core and using the same temperature of the heat source, the temperature at the opposite surface of core drastically decreases up to $90^{\circ} \mathrm{C}$, Figure $1 \mathrm{~b}$, due by the thermal conductivity of the TBC and its thickness [1-3].

(a) Metal without Thermal Barrier

$\mathrm{T}_{1} \sim \mathrm{T}_{2}$

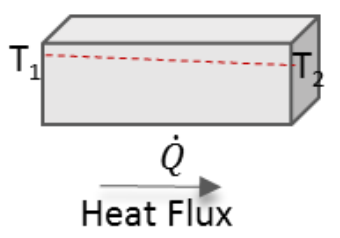

\section{$\mathrm{T}$}

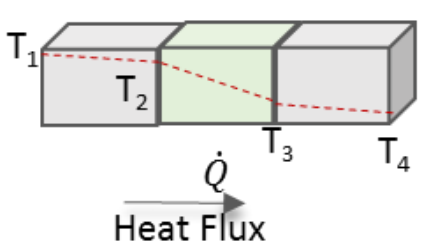

Figure 1 Temperature profile (a) surface without TBC, (b) surface with TBC

Source: own work [Power Point]

TBC not only act as thermal insulators; they also reduce the wear of metal core due by corrosion caused by its exposure to high temperatures; for example, Amaya 2009 report that a turbine blade without TBC; after $2500 \mathrm{hr}$ of flight at low altitude over the sea showed several damage from pitting corrosion, meanwhile a blade with a Ni-Al TBC have no signal of wear or corrosion [3].

Among the most commonly materials used as a TBC are the ceramics shown in Table 1. These materials have low thermal conductivity $(\mathrm{k})$; based on zirconium oxide $\left(\mathrm{ZrO}_{2}\right)$ and $\mathrm{TBC}$ of iridium stabilized zirconium oxide (YSZ) which have an average $\mathrm{k}$ value of $2 \mathrm{~W} /(\mathrm{mK})$ [4-8]. TBCs are commonly formed by expensive metal oxides such as $\mathrm{Ba}, \mathrm{Zr}, \mathrm{Ce}$, La, etc.

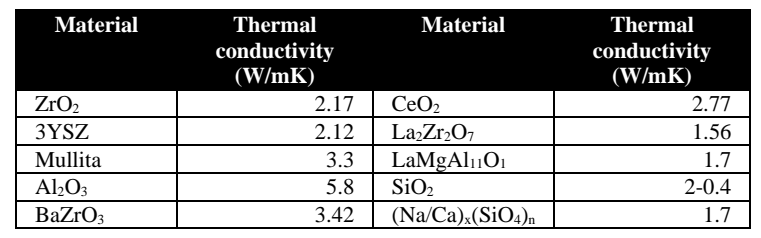

Table 1 Thermal conductivity for $\mathrm{TBC}$ and vitreous silica

Source: own work [Word]

Among the oxides with low conductivity with low cost are vitreous silica $(\mathrm{K}=2$ to $0.4 \mathrm{~W}$ / $\mathrm{mK}$ ) and silicates (1.7 W / $\mathrm{mK})$ however, these oxides have a low thermal expansion coefficient between 0.5 to $9 \times 10^{-6} 1 /{ }^{\circ} \mathrm{C}$; that implies little capacity for thermal deformation. This complicates its use as TBC because its limited deformability at high temperatures compared to metals; for example, for steels the thermal expansion is ranging from 12 to 18 $\mathrm{X} 10^{-6} 1 /{ }^{\circ} \mathrm{C}$.

Recently, Salazar-Hernández C et al. [912] have studied ceramic coatings based on polydimethylsiloxane-modified silica (PDMS) as anticorrosive coatings. In this project it is proposed to study the thermal properties of these coatings, considering silica with low thermal conductivity ( $1.48 \mathrm{~W} / \mathrm{m} \mathrm{K})$. However, its coefficient of thermal expansion is different from a metal, thus, it is proposed to add an organic modifier to the ceramic such as polydimethylsiloxane (PDMS). PDMS is an elastomeric silicone with high thermal stability that could offer the ceramic structure greater flexibility as indicated in Figure 2.

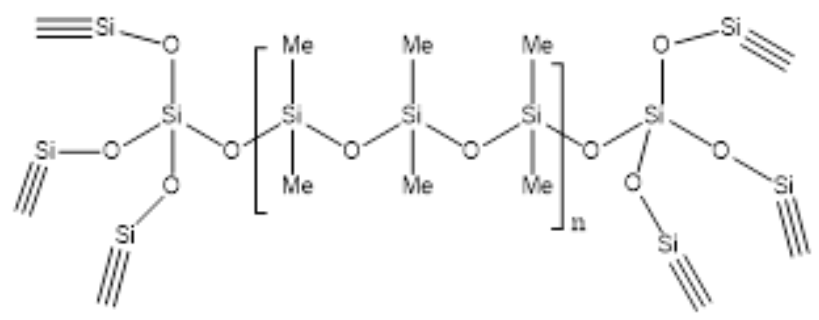

Figure $2 \mathrm{SiO}_{2} / \mathrm{PDMS}$ ceramic structure Source: own work [ChemDraw]

However, PDMS contains organic groups in its siloxane chain, thus, the thermal stability of material can be compromised at temperatures greater than $200{ }^{\circ} \mathrm{C}$; Therefore, it is proposed a thermal densification treatment in order to increase thermal stability for the ceramic. Analyzing the effect of thermal densification treatment on thermal conductivity and corrosion resistance. 


\section{MethodologySiO2 / PDMS Synthesis}

The sol was obtained according to the methodology proposed by Salazar-Hernández et al [7]; where the TEOS (99\%, Aldrich) is mixed with different percentage of PDMS (Gelest, 16-32 sct) adding DBTL maintaining the ratio of 99: 1 TEOS: DBTL (Table 2). The mixture is heated during $30 \mathrm{~min}$ at $50{ }^{\circ} \mathrm{C}$ before being applied to AISI-1018 steel surface.

\begin{tabular}{|l|r|r|}
\multicolumn{1}{c}{} & \multicolumn{1}{c|}{$\%$ Components } \\
& \multicolumn{1}{c}{ SiO $_{2}$} & \multicolumn{1}{c|}{ PDMS } \\
\hline TBC-10 PDMS & 90 & 10 \\
\hline TBC-20 PDMS & 80 & 20 \\
\hline TBC-30 PDMS & 70 & 30 \\
\hline TBC-40 PDMS & 60 & 40 \\
\hline TBC-PDMS & --- & 100 \\
\hline
\end{tabular}

Table 2 Synthesis for ORMOSIL-UPIIG coatings Source: own work [word]

\section{TBC application on AISI-1018 steel}

The steel surface is pre-treated in order to remove impurities; This treatment consist of roughing the surface with abrasive paper to remove impurities, then ethyl alcohol was performed using an ultrasonic bath for $10 \mathrm{~min}$ (Ultrasonic Cleaner-Intertek Listed) and finally dried at room temperature. The application of the TEOS / PDMS sol solution to the steel surface was carried out with the dip-coating technique.

\section{Densification Process}

To increase the thermal stability of the coatings, these were subjected to a thermal densification treatment indicated in Table 3.

\begin{tabular}{|c|c|c|c|}
\hline & $\begin{array}{l}\text { Temperature } \\
\left({ }^{\circ} \mathrm{C}\right)\end{array}$ & $\begin{array}{l}\text { Time } \\
\text { (min) }\end{array}$ & $\%$ PDMS \\
\hline \multirow{3}{*}{$\mathbf{T 1}$} & 30 & 30 & \multirow{3}{*}{$\begin{array}{l}10 \% \text { and } \\
20 \%\end{array}$} \\
\hline & 80 & 60 & \\
\hline & 500 & 120 & \\
\hline \multirow{3}{*}{$\mathbf{T} 2$} & 80 & 30 & \multirow{3}{*}{$\begin{array}{l}30 \text { and } \\
40 \%\end{array}$} \\
\hline & 200 & 120 & \\
\hline & 400 & 120 & \\
\hline
\end{tabular}

Table 3 Temperature ramps used for the densification process

Source: own work [Word]

\section{Chemical characterization}

Infrared spectroscopy (IR-TF) was used to chemically characterize the coatings, with this technique the main components of these TBC were identified. The spectra were obtained with a Nicolet-iS10 ATR-TF spectrometer, with an average of 16 scans and a resolution of $4 \mathrm{~cm}^{-1}$ with a spectral window of 4000 to $600 \mathrm{~cm}^{-1}$.

\section{Corrosion Rate}

To perform this test, the Peak Tech corrosion test bench model DIT-105 was used, applying a constant current of $0.5 \mathrm{~A}$ for 90 minutes. The corrosive agent used was sodium chloride with a concentration of $5 \%$ by weight. The corrosion rate $\left(\mathrm{V}_{\mathrm{c}}\right)$ was determined by gravimetry according to Equation 1; where $\Delta \mathrm{m}$ is the loss of mass in grams generated by corrosion, $\mathrm{A}$ is the exposed area in $\mathrm{m}^{2}$ and $\mathrm{t}$ the exposure time of the material in seconds.

$V_{c}=\frac{\Delta m}{A * t}[=] \frac{k g}{m^{2} \cdot s}$

\section{Measurement of Thermal Conductivity}

The thermal conductivity was determined using the measurement test rig shown in Figure 3. The test rig consists of a test section that is limited to cubic specimens with a length of 25.4 $\mathrm{mm}$, the section is insulated with fiberglass to promote heat flow in the $\mathrm{Z}$ direction. As a heat source a resistance of $100 \mathrm{~W}$ was placed at the bottom of specimen, thus, heat flux is controlled by an on / off control device based on Arduino; which is connected to a computer to record the temperature of the heat source and the top of the specimen.

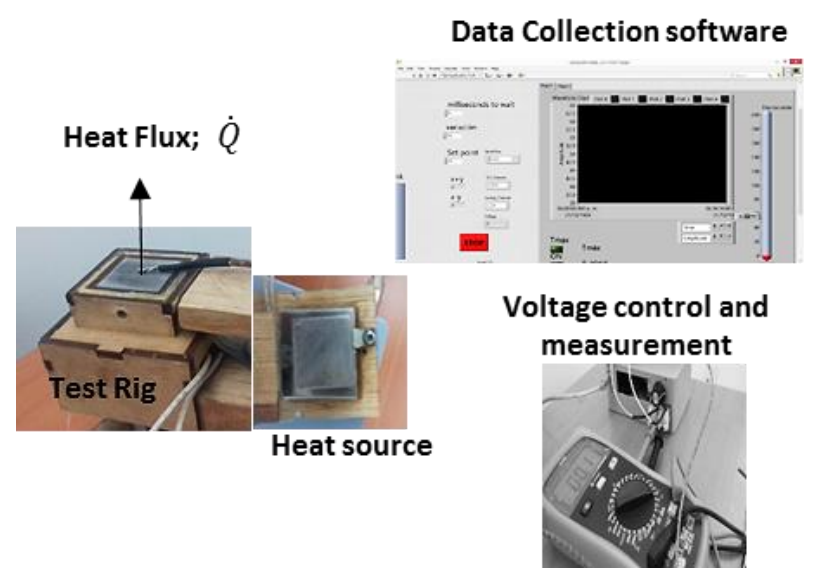

Figure 3 Test bench used to determine the thermal conductivity of materials and TBC Source: own work [Power Point] 
The heat flux supplied was calculated by Ec. 2 for which the voltage (V) and current (i) were measured during the test. Because the contact area of the specimen is different from the total resistance area; Q is adjusted with the correction factor $\mathrm{Fc}$, as shown in Equation 3.

$$
\begin{aligned}
& Q=F_{c}(i \cdot V) \\
& F_{c}=\frac{A_{\text {probeta }}}{A_{\text {resistencia }}}
\end{aligned}
$$

Thermal conductivity was calculated using Fourier's law for composite walls; (Equation 4) where $\mathrm{Q}$ is the heat flux through the specimen, $\mathrm{L}$ is the layer length, $\mathrm{K}$ is the thermal conductivity for each section and $\mathrm{A}$ is the normal heat transfer area for each component.

$Q=\frac{T_{i}-T_{i+1}}{\sum_{i}^{n}\left(\frac{L}{k A}\right)_{i}}$

\section{Results}

\section{$\mathrm{SiO}_{2} / \mathrm{PDMS}$ as TBC composition}

Figure 4 shows the ATR-FT for these ceramics; where the $3600 \mathrm{~cm}^{-1}$ signal corresponds to the terminal hydroxyl of the PDMS and there dissapear; on the other hand, the signals of the organic groups of TEOS ($\left.\mathrm{CH}_{2}-\mathrm{CH}_{3}\right)$ are observed between $2900-300 \mathrm{~cm}^{-}$ ${ }^{1}$ and $1400-1600 \mathrm{~cm}^{-1}$ but also not identified. This confirms that the DBTL promoted polycondensation between both reagents, forming the structure of the proposed TBC; where at $2900 \mathrm{~cm}^{-1}$ (signal 2) the $-\mathrm{CH}_{3}$ linked to the polysiloxane chain "PDMS" embedded between the ceramic particles are observed; the silica network of the ceramic is identified with the signal 1 corresponding to the siloxane groups (-Si-O-Si) that were observed around $1017 \mathrm{~cm}^{-1}$ as a broad band; that for CBT with $40 \%$ PDMS an intense shoulder is formed at $1192 \mathrm{~cm}^{-1}$; In addition, linear siloxanes from PDMS are identified with the fine signal between $780-796 \mathrm{~cm}^{-1}$ [13].

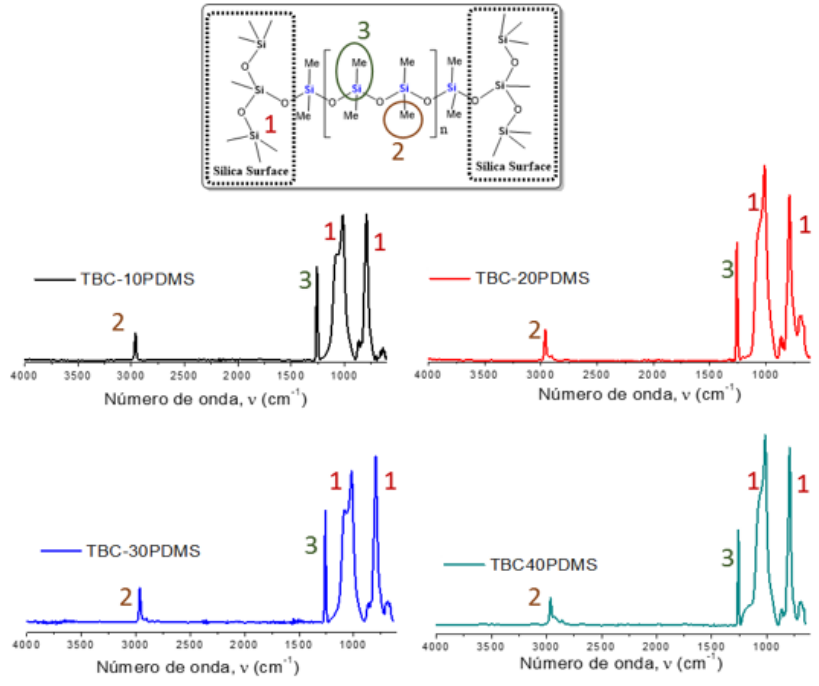

Figure 4 Characterization by ATR-FT for $\mathrm{SiO}_{2} /$ PDMS TBCs

Source: own work [Power Point and Origin]

\section{$\mathrm{SiO}_{2} / \mathrm{PDMS}$ densification}

Figure 5 shows the graphs obtained with the infrared analysis for TBCs exposed to heat treatments; it can be seen that the ramps used achieve the decrease of organic matter on the surface of the coating by about $80 \%$. The signals of the $-\mathrm{CH}_{3}$ groups at $2900 \mathrm{~cm}^{-1}$ and the Si-C signal at $1200 \mathrm{~cm}^{-1}$ almost disappear after the densification treatment has been performed. In addition, the band corresponding to the siloxanes (silica network, -Si-O-Si) at $1100 \mathrm{~cm}^{-1}$ is widened, which suggests that the linear chains of the PDMS condense forming a compact structure.
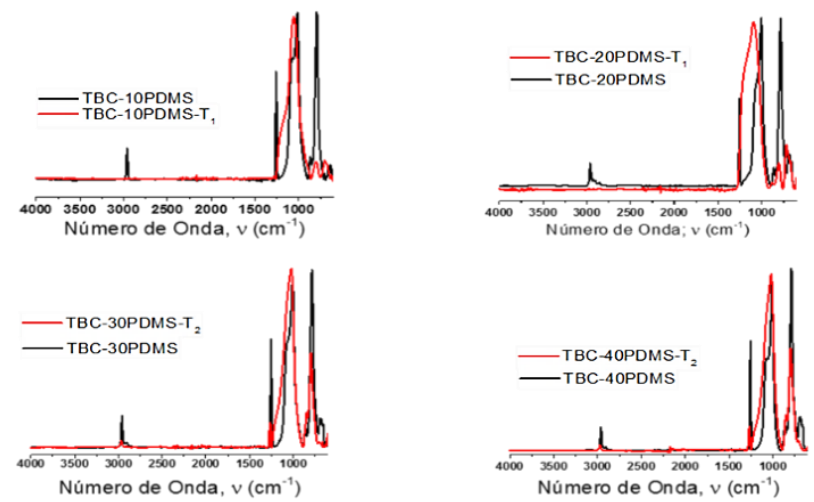

Figure 5 Modification of $\mathrm{SiO} 2$ / PDMS after densification by ATR-FT Source: own work [origin] 
Figure 6 shows scanning electron microscopy (SEM) for ceramics before and after heat treatment; where it is appreciated that by increasing the amount of PDMS precipitates in the silica network indicated by red circles. When densified; these groups generate fractures in the film formed probably because the increase in temperature causes their detachment generating an increase in stress that causes the fissure of the coating; which was major at TBC-100PDMS.

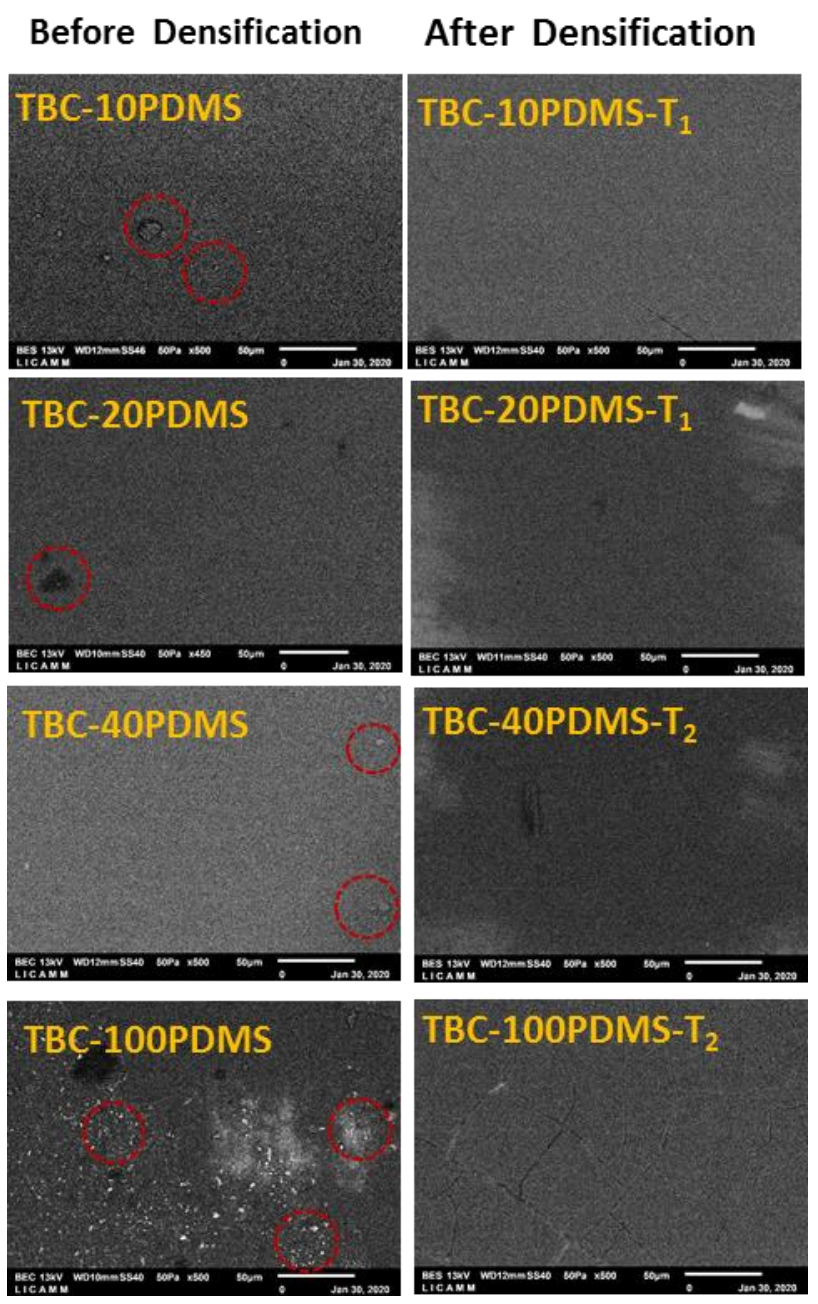

Figure 6 SEM for SiO2/PDMS TBC Source: own work [PowerPoint]

\section{Corrosion test}

Figure 7 shows the corrosion rate determined in $\mathrm{mm}$ of penetration per year for the TBC of $\mathrm{SiO}_{2} / \mathrm{PDMS}$ with and without densification treatment; where the coating without densification presented a corrosion rate of 0.27 $\mathrm{mm} /$ year.
When densifying the SiO2/PDMS, the anticorrosive activity in the ceramic is increased by $94 \%$. The corrosion rate for these materials was about $0.02 \mathrm{~mm} /$ year.

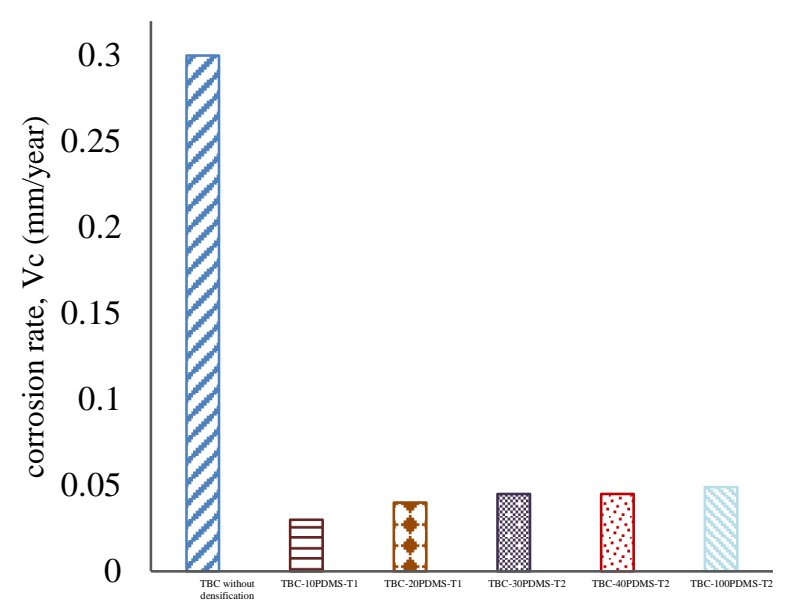

Figure 7 Corrosion rate for $\mathrm{TBC}^{\mathrm{SiO}} / 2 / \mathrm{PDMS}$ Source: own work [Excel]

\section{Thermal conductivity for $\mathrm{SiO}_{2} / \mathrm{PDMS}$}

The thermal conductivity for the AISI-1018 ranges from 50 to $56 \mathrm{Wm}-1 \mathrm{~K}-1$ in the temperature range of $50-150^{\circ} \mathrm{C}$; for this metal there is no considerable effect of temperature on the thermal property. However; different values were determined for the TBC-SiO2 / PDMS. According to Figure 8, no significant effect was observed in the PDMS content on the conductivity of the TBCs. Calculating an average value of $4.19 \pm 0.16 \mathrm{Wm}-1 \mathrm{~K}-1$ at $50^{\circ} \mathrm{C}$, $15.96 \pm 2.12 \mathrm{Wm}-1 \mathrm{~K}-1$ at $100^{\circ} \mathrm{C}$ and $42.38 \pm$ $4.09 \mathrm{Wm}-1 \mathrm{~K}-1$.

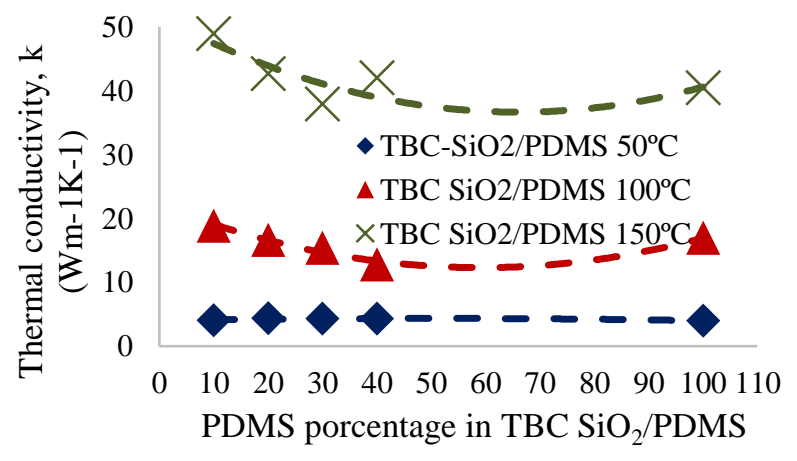

Figure 8 Effect of PDMS concentration on termal conductivity

Source: own work [Excel] 
According to the increase in temperature, an increase in conductivity was observed and a greater deviation between the values of $\mathrm{K}$. This is because the thermal stability of the TBC depends on the PDMS content. Then, to improve this property, the coatings were densified to obtain the conductivity values indicated in Figure 9.

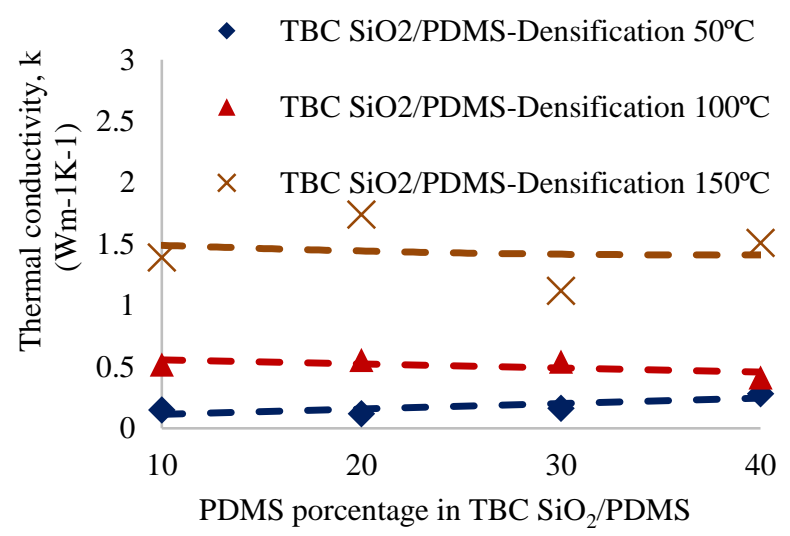

Figure 9 Effect of densification on thermal vonductivity

Source: own work [Excel]

After the densification treatment, the conductivity decreased to observe an average of $0.179-0.071 \mathrm{Wm}^{-1} \mathrm{~K}^{-1}$ at $50{ }^{\circ} \mathrm{C}, 0.507$ $\pm 0.065 \mathrm{Wm}^{-1} \mathrm{~K}^{-1}$ at $100{ }^{\circ} \mathrm{C}$ and 1.44 to $0.025 \mathrm{Wm}^{-1} \mathrm{~K}^{-1}$. Observing that the content of PDMS in the structure of the TBC has no effect on the value of $\mathrm{K}$. However, the temperature modifies the $\mathrm{K}$ linearly for the $\mathrm{TBC}^{-\mathrm{SiO}_{2}} /$ PDMS (Figure 10).

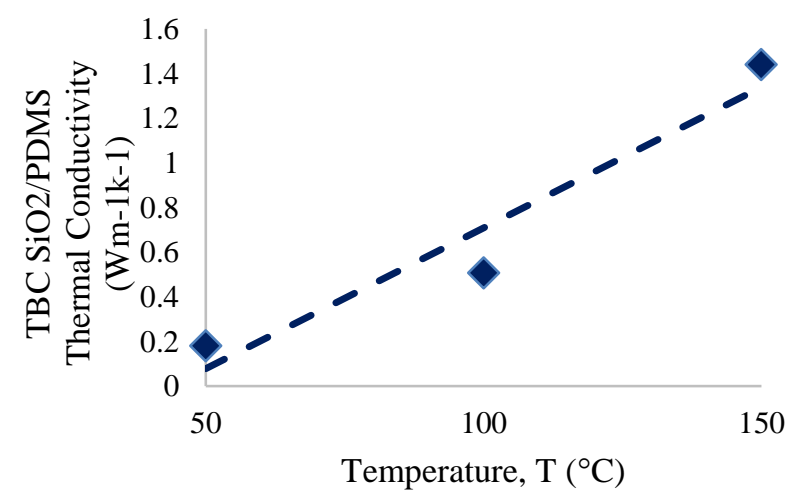

Figure 10 Temperature effect on $\mathrm{TBC}-\mathrm{SiO}_{2} / \mathrm{PDMS}$ termal conductivity

Source: own work [Excel]

\section{Conclusions}

The ORMOSIL-UPIIG ceramic coating has a good performance as an anticorrosive coating for aluminum surfaces reducing the corrosion rate by $93 \%$.
However, densification increases the properties of the material by eliminating the microporosity formed in the ceramic structure. Therefore, this reduces the corrosion rate of aluminum by $99.5 \%$.

\section{Acknowledgments}

The authors acknowledge to the Secretary of Research and Postgraduate of Instituto Politécnico Nacional for the support provided through the project SIP-20201677 and SIP20201910. In addition, the LICAMM-UG is acknowledge for its support in the characterization by MEB.

\section{References}

1) Fernández-Rojas F, Rondón E, FernándezRojas C.J, Salas P. K.J, Grcía V.J, Barreras Térmicas y Nuevos Materiales, Rev. Fac. Ing. UCV (2012) 27(1), p. 100-108.

2) Amaya Hoyos C.A; Recubrimientos de Barreras Térmicas. Revista Informador Técnico (2009) 73: 27-33

3) Ghosh S (2015) Thermal Barrier Ceramic Coatings-A Review. In Advanced Ceramic Processing. Edited by Mohamed A, IntechOpen, pp. 111-138

4) Zhilin T, Liya Z, Jiemin W, Peng W, Jialin $\mathrm{L}$, Jingyang $\mathrm{W}$; Theoretical and experimental determination of the major thermomechanical properties of RE2SiO5 $(\mathrm{RE}=\mathrm{Tb}, \mathrm{Dy}, \mathrm{Ho}, \mathrm{Er}, \mathrm{Tm}, \mathrm{Yb}, \mathrm{Lu}$, and $\mathrm{Y})$ for environmental and thermal barrier coating applications; Journal of the European Ceramic Society (2016) 36: 189202

5) Jing Z, Xingye G, Yeon-Gil J, James, K; Lanthanium zirconate based thermal barrier coating: a review (2017) Surface \& Coating Technology, 323:18-29

6) Soleimanipour Z, Baghshane S, ShojaRazavi R, Salehi M; Hot corrosion behavior of $\mathrm{Al} 2 \mathrm{O} 3$ laser clad plasma sprayed YSZ thermal barrier coating; Cermics International (2016) 42: 1769817705 
7) Sánchez-Rivera, M. J., Orts, M. J., PérezHerranz, V., \& Mestre, S. Effect of type and amount of alumina as dopant over the densification and the electrical properties of zinc oxide ceramic electrodes. Boletín de la Sociedad Española de Cerámica y Vidrio (2020). Article in Press. https://doi.org/10.1016/j.bsecv.2020.01.00 3

8) Taborda-Barraza, M., de Azevedo, N. H., Gleize, P. J. P., \& Prieto, N. (2020). Análisis comparativo de las propiedades mecánicas de geopolímeros que incorporan nanowhiskers de $\mathrm{SiC}$ y nanopartículas de TiO2. Revista UIS Ingenierías, (2020) 19(1), 95-102.

9) Salazar-Hernández C, Salazar-Hernández M, Carrera-Cerritos R, Mendoza-miranda J.M, Elorza-Rodríguez E, Miranda-Avilés $\mathrm{R}$, Moncada-Sánchez D, Anticorrosive properties of PDMS-Silica coatings: effect of methyl, phenyl and amino groups", Progress in Organic Coating (2019)136, 105220

10) Salazar-Hernández $C$, Salazar-Hernández M, Mendoza-Miranda J.M, MirandaAvilés R, Elorza-Rodríguez E, CarreraRodríguez R, Puy-Alquiza M.J, Organic modified silica obtained from DBTL polycondensation catalyst for anticorrosive coating, J. Sol-Gel Sci and Technol (2018) 87 (2), 229-309.

11) Salazar-Hernández $C$, Salazar-Hernández M, Carrera-Cerritos R, Elorza E, Mendoza-Miranda J.M, Navarro R, DBTL as neutral catalyst on TEOS/PDMS anticorrosive coating, J. Sol-Gel Sci and Technol (2017) 81, 405412.

12) Pájaro Hernández, M. G. (2019). Materiales híbridos: Síntesis y caracterización de materiales a base TEOS-PDMS-Pal utilizados como soporte inicial para la proliferación de osteoblastos MG-63. Tesis Ingeniería Metalurgia y Materiales ESIQIE-Instituto Politécnico Nacional.
13) Launer PJ (1987) Infrared analysis of organosilicon compounds: spectra structure correlation silicon compounds. In: Arkles B (ed) Gelest Inc: Morrisville, PA. 